Article

\title{
Cerebral MRI and Clinical Findings in Children with PTEN Hamartoma Tumor Syndrome: Can Cerebral MRI Scan Help to Establish an Earlier Diagnosis of PHTS in Children?
}

\author{
Michaela Plamper ${ }^{1, *, \dagger}$, Mark Born ${ }^{2,+}{ }^{\oplus}$, Bettina Gohlke ${ }^{1} \mathbb{D}$, Felix Schreiner ${ }^{1}$, Sandra Schulte ${ }^{1}$, \\ Vera Splittstößer ${ }^{1}$ and Joachim Woelfle ${ }^{1,3}$ \\ 1 Children's Hospital, Department of Pediatric Endocrinology and Diabetology, University of Bonn, \\ Venusberg-Campus 1, 53127 Bonn, Germany; bettina.gohlke@ukbonn.de (G.B.); \\ Felix.Schreiner@ukbonn.de (S.F.); Sandra.Schulte@ukbonn.de (S.S.); Vera.Splittstoesser@ukbonn.de (S.V.); \\ joachim.woelfle@uk-erlangen.de (W.J.) \\ 2 Department of Radiology, Pediatric Radiology, University Hospital Bonn, Venusberg-Campus 1, \\ 53127 Bonn, Germany; mark.born@ukbonn.de \\ 3 Children's Hospital, University of Erlangen, Loschgestrasse 115, 91054 Erlangen, Germany \\ * Correspondence: Michaela.Plamper@ukbonn.de; Tel.: +49-228-28733223; Fax: +49-228-28733472 \\ + These authors contributed equal to this work.
}

Received: 13 June 2020; Accepted: 8 July 2020; Published: 10 July 2020

check for updates

\begin{abstract}
Background: PTEN Hamartoma Tumor Syndrome (PHTS) is caused by germline autosomal -dominant mutations of the tumor suppressor gene PTEN. Subjects harbour an increased risk for tumor development, with thyroid carcinoma occurring in young children. Establishing a diagnosis is challenging, since not all children fulfill diagnostic criteria established for adults. Macrocephaly is a common feature in childhood, with cerebral MRI being part of its diagnostic workup. We asked whether distinct cMRI features might facilitate an earlier diagnosis. Methods: We retrospectively studied radiological and clinical data of pediatric patients who were presented in our hospital between 2013 and 2019 in whom PTEN gene mutations were identified. Results: We included 27 pediatric patients (18 male) in the analysis. All patients were macrocephalic. Of these, 19 patients had received at least one cMRI scan. In 18 subjects variations were detected: enlarged perivascular spaces (EPVS; in 18), white matter abnormalities (in seven) and less frequently additional pathologies. Intellectual ability was variable. Most patients exhibited developmental delay in motor skills, but normal intelligence. Conclusion: cMRI elucidates EPVS and white matter abnormalities in a high prevalence in children with PHTS and might therefore aid as a diagnostic feature to establish an earlier diagnosis of PHTS in childhood.
\end{abstract}

Keywords: PTEN; PHTS; children; cMRI; enlarged perivascular spaces; Virchow-Robin spaces; white matter abnormalities; macrocephaly

\section{Introduction}

PTEN hamartoma tumor syndrome (PHTS) is caused by germline autosomal-dominant mutations of the tumor suppressor gene PTEN. PHTS encompasses different syndromic disorders including Cowden syndrome (CS), Bannayan Riley Ruvalcaba Syndrome (BRRS), Lhermitte Duclos Syndrome, Proteus and Proteus like syndrome. In addition, juvenile polyposis of infancy, autism spectrum disorders with macrocephaly and children with macrocephaly and developmental delay and/or cognitive impairment are associated with PTEN gene mutations. All individuals with molecularly 
proven PTEN mutation are at increased risk of developing benign or malignant tumors and therefore benefit from cancer surveillance strategies. Most frequently, tumor development is described in breast, endometrium and thyroid. In addition, other organs like the skin, colorectal, renal and central nervous systems can be affected [1]. The development of thyroid carcinoma has been described in young children [2-4]. Thus, it is important to make an early diagnosis to implement screening examinations.

Macrocephaly (MC) is an important clinical feature to initiate genetic testing of the PTEN gene and therefore an important criterion for a diagnosis of PTEN gene mutation and PHTS in childhood $[5,6]$. Several publications reported a prevalence of up to $100 \%$ in pediatric patients [7-11]. In early childhood, macrocephaly seems to be the only or the most evident symptom. The diagnostic workup of non-familial increased head circumference in children $(>+2$ SDS above the age and population related mean or $>97$ th percentile) is done using a cerebral MRI scan.

In the current literature, different neuroimaging features associated with PTEN mutations have been reported, including cerebellar dysplastic gangliocytoma (Lhermitte-Duclos disease (LDD)), meningioma, vascular malformations [12], localized malformations such as focal cortical dysplasia, white matter abnormalities [13], dilated Virchow-Robin spaces [14] and polymicrogyria [15]. Since our institution hosts a rare disease center for familiar tumor syndromes, we have the opportunity to supervise a relatively large pediatric cohort of patients with PHTS. Most of these patients had received at least one cerebral MRI, frequently before establishing a diagnosis of PHTS. Based on the pre-diagnostic MRI findings, we wondered whether distinct features of cerebral MRIs in PHTS might help to establish an earlier diagnosis in children.

\section{Methods}

We retrospectively studied all available data of our cohort of patients with molecular-proven PHTS, who had presented in our pediatric department for endocrinology between the years 2013 and 2019.

The PHTS patients did not primarily visit our department because of endocrinological problems, but because we established a PHTS clinic as part of our center for rare diseases. Because all data presented in this analysis were included in routine care of these subjects and no additional examinations were performed, we did not request for additional ethics clearance.

Clinical features of our patients were collected, concentrating on psychomotor milestones of motor and language development as well as additional neurological findings. In patients in whom a cerebral MRI scan (cMRI) had been performed previously, we asked the families for permission to analyze their cMRI. All participating families gave consent for analysis of pre-diagnostic radiological data. Either families gave us their own copies of cMRI for analysis or they gave us consent to contact the operating institutes to send us a copy of the cMRI pictures.

The majority of MRI scans were performed as part of the initial clinical routine in a local institution, so that cMRI techniques did not follow a standardized approach.

The examinations were performed with scanners from different manufacturers, and with different examination protocols in local operating institutes. In all cases, a field strength of $1.5 \mathrm{~T}$ was used. Five patients had only native cMRI, all other patients had at least one MRI with contrast medium. In almost all examinations the following standard sequences were used: T2 weighted fast spin echo, $\mathrm{T} 1$ spin echo and fluid attenuated inversion recovery (FLAIR). On the other hand there were significant differences in the technical parameters, for example the slice thickness in fast spin echo varied from 2.5 to $6 \mathrm{~mm}$ and in T1 spin echo from 3 to $6 \mathrm{~mm}$. Soft tissue contrast is significantly influenced by the echo time, which varied from 80 to $130 \mathrm{~ms}$ in fast spin echo, and from 90 to $150 \mathrm{~ms}$ in FLAIR. Inversion time in FLAIR differed from 1800 to $2850 \mathrm{~ms}$. Because of the described diversity, a quantification of the different examinations and their signal intensity would be difficult. Moreover, signal intensity especially of the white matter is age-dependent. Therefore, we did not use a software program to quantify the signal intensity. 


\section{Results}

We included 27 pediatric patients (18 male and nine female patients) in the present study. Age at diagnosis of the PTEN mutation ranged from eight months to 13.5 years.

In most cases, genetical analysis was performed within the diagnostic workup for a combination of macrocephaly, developmental delay and other clinical features such as penile freckling or lipoma. In two cases (patient 9 and 16), the responsible physicians recommended PTEN gene analysis because of the combination of macrocephaly and enlarged perivascular spaces (EPVS). In two additional patients, diagnosis was made, because of a thyroid pathology and macrocephaly (follicular adenoma and macrocephaly-patient 10; follicular carcinoma and macrocephaly-patient 19).

The youngest patient, who had received a cerebral MRI scan was three months old. The age distribution at performance of cerebral MRI scan is depicted in Table 1.

\subsection{Macrocephaly}

As reported before [11], all patients of this study exhibited macrocephaly by the age of two years. Stratified for different age groups the mean head-circumference SDSs for boys was above +4 SDS, and for girls, above +3 SDS.

\section{2. $M R I$}

Nineteen out of twenty-seven patients (13/18 male patients (72\%) and 6/9 female (67\%) patients) had received at least one cerebral MRI scan. The age at cMRI in our patient cohort ranged from infancy to early adolescence (for details see Table 1); different institutions used different technical conditions. Some patients received one or more follow up cerebral MRI examination to follow-up on conspicuous results.

Eighteen of nineteen patients exhibited variations in cMRI. In 17 of 19 patients, we were able to re-analyze the MRI scans. In two cases, we only obtained medical reports, which were reported to be normal, even though enlarged perivascular spaces were described in one of these two patients. Medical reports of our patient cohort described enlarged perivascular spaces (EPVS), also known as Virchow-Robin Spaces (VRS), in six patients. However, when we re-analyzed the MRI pictures with special focus on EPVS, we found enlarged perivascular spaces in a total of eighteen patients (18/19). In some patients, these findings were quite evident (Figure 1b). Seven patients (7/17) presented with white matter abnormalities (Figure 2). Further pathologies included a cavernoma at the right side of the cerebellum, subependymal heterotopia at the top of the lateral cerebral ventricle, arachnoid cysts (in two), a Chiari malformation type I and a clinical diagnosis of pseudotumor cerebri with ventriculoperitoneal shunt in one patient (Table 1). 
Table 1. Cerebral MRI scan and neurological features in 27 pediatric PHTS subjects

\begin{tabular}{|c|c|c|c|c|c|c|c|c|c|c|c|}
\hline Pat.No & Sex & $\begin{array}{l}\text { Mutation/Deletion in } \\
\text { PTEN Gene } \\
\text { (Localisation) }\end{array}$ & $\begin{array}{l}\text { Age at } \\
\text { DIAGNOSIS } \\
\text { (Years) }\end{array}$ & $\begin{array}{l}\text { Age at cMRI } \\
\text { (Years) }\end{array}$ & Results of cMRI Scan & $\mathrm{IQ}>85$ & $\begin{array}{c}\text { Delay in } \\
\text { Motor } \\
\text { Develop-ment }\end{array}$ & $\begin{array}{c}\text { Muscle } \\
\text { Hypotonia }\end{array}$ & $\begin{array}{l}\text { Confirmed } \\
\text { Autism }\end{array}$ & $\begin{array}{l}\text { More Detailed Description } \\
\text { of Neurological Features } \\
\text { and Academic Performance }\end{array}$ & $\begin{array}{c}\text { Age at Start of } \\
\text { Walking } \\
\text { Independently } \\
\text { (Months) }\end{array}$ \\
\hline 1 & male & $\begin{array}{l}\text { c. } .389 \mathrm{G}>\text { A; Arg130 } \\
\text { Gln (exon 5) }\end{array}$ & 3.8 & n.d. & n.d. & + & + & - & - & $\begin{array}{l}\text { moderate delay in motor } \\
\text { development, normal } \\
\text { intelligence, secondary school } \\
\text {-> university }\end{array}$ & 22 \\
\hline 2 & male & $\begin{array}{l}\text { c. } 389 \mathrm{G}>\mathrm{A} ; \mathrm{Arg} 130 \\
\mathrm{Gln}(\text { exon 5) }\end{array}$ & 4 & $\begin{array}{l}0.25 \\
2.5\end{array}$ & enlarged perivascular spaces & - & + & + & + & $\begin{array}{l}\text { muscle hypotonia, autism, } \\
\text { developmental delay in motor } \\
\text { and language development, } \\
\text { no expressive speech }\end{array}$ & 26 \\
\hline 3 & male & $\begin{array}{l}\text { c.540C > A; p.Y Y } 180 \mathrm{X} \\
\text { (exon 6) }\end{array}$ & 5.3 & 6 & enlarged perivascular spaces & + & + & - & - & $\begin{array}{l}\text { delay of fine motor skills, } \\
\text { normal intelligence, } \\
\text { secondary school }\end{array}$ & 18 \\
\hline 4 & male & $\begin{array}{c}\text { c.737C > } \\
\text { T.p.Pro246Leu (exon 7) }\end{array}$ & 1.3 & & normal MRI scan (reported) & + & - & - & - & $\begin{array}{l}\text { None, normal intelligence, } \\
\text { secondary school }\end{array}$ & 17 \\
\hline 5 & male & $\begin{array}{l}\text { c. } 209+5 \mathrm{G}> \\
\text { A (Intron 3) }\end{array}$ & 2 & 1.75 & $\begin{array}{l}\text { white matter abnormalities, } \\
\text { (periventricular posterior } \\
\text { white matter), enlarged } \\
\text { perivascular spaces }\end{array}$ & + & + & - & - & $\begin{array}{l}\text { delay of gross and fine motor } \\
\text { skills, normal intelligence, } \\
\text { impulsivity, secondary school }\end{array}$ & 18 \\
\hline 6 & male & $\begin{array}{l}\text { c. } 445 \mathrm{C}>\mathrm{T} ; \mathrm{G} \ln 149 \mathrm{X} \\
\quad(\text { exon } 5)\end{array}$ & 3 & 2.0 & $\begin{array}{l}\text { white matter abnormalities } \\
\text { (posterior horn up to parietal } \\
\text { white matter; smaller frontal } \\
\text { and periventricular lesions), } \\
\text { enlarged perivascular spaces }\end{array}$ & + & - & - & - & $\begin{array}{l}\text { None, normal intelligence, } \\
\text { elementary school }\end{array}$ & 18 \\
\hline 7 & male & $\begin{array}{c}\text { c.509G > A; } \\
\text { pSer170Asn (exon 6) }\end{array}$ & 4 & n.d. & n.d. & + & + & - & - & $\begin{array}{l}\text { moderat delay in fine motor } \\
\text { skills, normal intelligence, } \\
\text { elementary school }\end{array}$ & 14.5 \\
\hline 8 & male & $\begin{array}{l}\text { heterozygous deletion } \\
\text { (exon 1-2) }\end{array}$ & 8 & $\begin{array}{c}4.5 \\
4.75 \\
5.3\end{array}$ & $\begin{array}{l}\text { Ventriculo-peritoneal shunt, } \\
\text { enlarged perivascular spaces }\end{array}$ & - & + & - & $(-)$ & $\begin{array}{l}\text { social behaviour problems, } \\
\text { impulsivity, developmental } \\
\text { delay, pseudotumor cerebri, } \\
\text { Difficulties in regular school }\end{array}$ & $?$ \\
\hline 9 & male & $\begin{array}{l}\text { partial deletion } \\
\text { (exon 6) }\end{array}$ & 1.5 & $\begin{array}{c}1 \\
2.5 \\
4.5\end{array}$ & $\begin{array}{l}\text { Periventricular, occipital, } \\
\text { parietal and and smaller } \\
\text { frontal white matter } \\
\text { abnormalities; enlarged } \\
\text { perivascular spaces }\end{array}$ & + & + & + & - & $\begin{array}{l}\text { muscle hypotonia, moderate } \\
\text { delay in motor development, } \\
\text { normal intelligence, } \\
\text { secondary school } \\
\text { diagnosis of PHTS because of } \\
\text { MC and EPVS }\end{array}$ & 20 \\
\hline 10 & male & $\begin{array}{c}\text { c.697C > } \\
\text { T;pArg233*(exon 7) }\end{array}$ & 11 & n.d. & n.d. & + & - & - & - & $\begin{array}{l}\text { None, normal intelligence, } \\
\text { secondary school }\end{array}$ & 18 \\
\hline
\end{tabular}


Table 1. Cont

\begin{tabular}{|c|c|c|c|c|c|c|c|c|c|c|c|}
\hline Pat.No & Sex & $\begin{array}{l}\text { Mutation/Deletion in } \\
\text { PTEN Gene } \\
\text { (Localisation) }\end{array}$ & $\begin{array}{l}\text { Age at } \\
\text { DIAGNOSIS } \\
\text { (Years) }\end{array}$ & $\begin{array}{l}\text { Age at cMRI } \\
\text { (Years) }\end{array}$ & Results of cMRI Scan & $\mathrm{IQ}>85$ & $\begin{array}{c}\text { Delay in } \\
\text { Motor } \\
\text { Develop-ment }\end{array}$ & $\begin{array}{l}\text { Muscle } \\
\text { Hypotonia }\end{array}$ & $\begin{array}{l}\text { Confirmed } \\
\text { Autism }\end{array}$ & $\begin{array}{l}\text { More Detailed Description } \\
\text { of Neurological Features } \\
\text { and Academic Performance }\end{array}$ & $\begin{array}{c}\text { Age at Start of } \\
\text { Walking } \\
\text { Independently } \\
\text { (Months) }\end{array}$ \\
\hline 11 & male & c. $959 \mathrm{~T}>\mathrm{G}\left(\mathrm{p}\right.$. Leu $\left.320^{*}\right)$ & 7.5 & $\begin{array}{l}0.3 \\
7.8 \\
8.3 \\
9.3\end{array}$ & $\begin{array}{l}\text { Cavernoma right side } \\
\text { cerebellum, enlarged } \\
\text { perivascular spaces; slight } \\
\text { parieto-occipital white } \\
\text { matter abnormalities }\end{array}$ & $\stackrel{+}{\mathrm{IQ}_{91}}$ & - & + & - & $\begin{array}{l}\text { muscle hypotonia, difficulties } \\
\text { in logical reasoning, } \\
\text { impulsivity normal } \\
\text { intelligence: HAWIK IV with } \\
8 \text { years: IQ 91 Special } \\
\text { needs school }\end{array}$ & 14 \\
\hline 12 & male & $\begin{array}{l}\text { c.987dup T (p.Lys330*) } \\
\text { (exon 8) }\end{array}$ & 6.5 & n.d. & n.d. & $\stackrel{+}{\mathrm{IQ}^{8} 84}$ & + & + & - & $\begin{array}{l}\text { muscle hypotonia WPPSI-III, } \\
\text { 2009-HAWIVA-III with } 6 \\
\text { years: IQ } 84, \\
\text { elementary school }\end{array}$ & 24 \\
\hline 13 & male & $\begin{array}{l}\text { c. }\left(492+1 \_493-1\right)_{-} \\
\left(1026+1 \_1027-1\right) \text { del }\end{array}$ & 0.9 & 0.6 & enlarged perivascular spaces & + & + & + & - & $\begin{array}{l}\text { muscle hypotonia, delay in } \\
\text { fine motor skills, normal } \\
\text { intelligence, kindergarten }\end{array}$ & 19 \\
\hline 14 & male & $\begin{array}{c}\text { heterozygous deletion } \\
\text { PTEN and BMPR1A } \\
\text { Gene }\end{array}$ & 0.7 & $\begin{array}{c}0.75 \\
2\end{array}$ & $\begin{array}{l}\text { arachnoid cysts left and right } \\
\text { of the pineal region, enlarged } \\
\text { perivascular spaces, parietal } \\
\text { and temporal white matter } \\
\text { abnormalities (left sided } \\
\text { pronounced), parietal } \\
\text { Pacchioni granulation }\end{array}$ & + & - & + & - & muscle hypotonia & 18 \\
\hline 15 & male & $\begin{array}{l}\text { c.800_801delAG } \\
\quad(\text { exon 7) }\end{array}$ & 10 & 4.5 & $\begin{array}{l}\text { enlarged perivascular spaces, } \\
\text { slight parietal white } \\
\text { matter abnormalities }\end{array}$ & $\begin{array}{l}-/+ \\
\text { IQ with } 4.5 \\
\text { years: } 70 ; \\
\text { with 5.9 years: } \\
\text { IQ 89 }\end{array}$ & + & - & - & $\begin{array}{l}\text { developmental delay in } \\
\text { speech, cognition and motor } \\
\text { development, HAWIWA III } \\
\text { with } 4.5 \text { years: 70; HAWIVA } \\
\text { III with } 5.9 \text { years: IQ } 89 \text {, } \\
\text { special needs school }\end{array}$ & 14 \\
\hline 16 & male & $\begin{array}{l}\text { c. } 464 a>\text { G; } \\
\text { p.Tyr155Cys }\end{array}$ & 12 & 11.75 & enlarged perivascular spaces & $\begin{array}{c}+ \\
\text { IQ } 85\end{array}$ & + & - & - & $\begin{array}{l}\text { problems in sense of balance, } \\
\text { dyslexia, panic attacks, } \\
\text { diagnosis of PHTS because of } \\
\text { MC and EPVS }\end{array}$ & $?$ \\
\hline 17 & male & $\begin{array}{l}\text { p.Arg130Ter*; } \\
\text { c.388C > T }\end{array}$ & 4.5 & n.d. & n.d. & + & + & - & - & $\begin{array}{l}\text { delay in motor development, } \\
\text { normal intelligence }\end{array}$ & 30 \\
\hline 18 & male & $\begin{array}{l}\text { c.266C > G } \\
\text { (p.Pro89Arg) }\end{array}$ & 9 & $\begin{array}{c}0.75 \\
2.25 \\
8\end{array}$ & $\begin{array}{l}\text { subependymal heterotopia at } \\
\text { the top of the right lateral } \\
\text { ventricle, enlarged } \\
\text { perivascular spaces }\end{array}$ & $\begin{array}{c}+ \\
\text { IQ } 93\end{array}$ & + & + & + & $\begin{array}{l}\text { delay in language and motor } \\
\text { development. autism, ADHD, } \\
\text { muscle hypotonia, } \\
\text { obsessive-compulsive } \\
\text { disorder, social behaviour } \\
\text { problems, HAWIK: IQ 93, } \\
\text { special needs school }\end{array}$ & 30 \\
\hline
\end{tabular}


Table 1. Cont

\begin{tabular}{|c|c|c|c|c|c|c|c|c|c|c|c|}
\hline Pat.No & Sex & $\begin{array}{l}\text { Mutation/Deletion in } \\
\text { PTEN Gene } \\
\text { (Localisation) }\end{array}$ & $\begin{array}{l}\text { Age at } \\
\text { DIAGNOSIS } \\
\text { (Years) }\end{array}$ & $\begin{array}{l}\text { Age at cMRI } \\
\text { (Years) }\end{array}$ & Results of cMRI Scan & $\mathrm{IQ}>85$ & $\begin{array}{l}\text { Delay in } \\
\text { Motor } \\
\text { Develop-ment }\end{array}$ & $\begin{array}{c}\text { Muscle } \\
\text { Hypotonia }\end{array}$ & $\begin{array}{l}\text { Confirmed } \\
\text { Autism }\end{array}$ & $\begin{array}{l}\text { More Detailed Description } \\
\text { of Neurological Features } \\
\text { and Academic Performance }\end{array}$ & $\begin{array}{l}\text { Age at Start of } \\
\text { Walking } \\
\text { Independently } \\
\text { (Months) }\end{array}$ \\
\hline 19 & female & $\begin{array}{l}\text { c.741dupA; } \\
\text { p.Pro248Thrfs*5 } \\
\quad(\text { exon } 7)\end{array}$ & 13.5 & n.d. & n.d. & + & - & - & - & $\begin{array}{l}\text { None, secondary school } \\
->\text { university }\end{array}$ & 13 \\
\hline 20 & female & $\begin{array}{c}\text { c.302T > C; } \\
\text { p.Ile101Thr (exon 5) }\end{array}$ & 5 & n.d. & n.d. & $\begin{array}{c}+ \\
\text { IQ } 89\end{array}$ & + & + & - & $\begin{array}{l}\text { global developmental delay, } \\
\text { muscle hypotonia, } \\
\text { IQ testing: } 89\end{array}$ & 24 \\
\hline 21 & female & $\begin{array}{l}\text { c.762dupA; } \\
\text { p.Val255Serfs*43 } \\
\quad(\text { exon } 7)\end{array}$ & 5.5 & 6.2 & enlarged perivascular spaces & $\stackrel{+}{\text { IQ } 96}$ & + & ++ & - & $\begin{array}{l}\text { severe muscle hypotonia, } \\
\text { difficulties in logical reasoning, } \\
\text { HAWIK-IV/WISC-IV: IQ 96, } \\
\text { special needs school }\end{array}$ & 24 \\
\hline 22 & female & $\begin{array}{l}\text { c.49C > T;p.Gln17* } \\
\text { (exon1) }\end{array}$ & 6.8 & 8.5 & $\begin{array}{l}\text { normal MRI scan, but } \\
\text { enlarged perivascular spaces } \\
\text { (reported) }\end{array}$ & $\stackrel{+}{\text { IQ } 95}$ & + & + & - & $\begin{array}{l}\text { ADHS, orofacial hypotonia, } \\
\text { delay in motor development, } \\
\text { normal intelligence, IQ with } \\
6 \text { years:95 } \\
\text { Problems in elementary school }\end{array}$ & 18 \\
\hline 23 & female & $\begin{array}{c}\text { c.1008C > G;p.Tyr336* } \\
\text { (exon 8) }\end{array}$ & 5.8 & $\begin{array}{c}2.75 \\
3 \\
10.75\end{array}$ & $\begin{array}{l}\text { extremely large perivascular } \\
\text { spaces, arachnoidal cysts }\end{array}$ & - & + & - & - & $\begin{array}{l}\text { problems in sense of balance, } \\
\text { ataxia, global developmental } \\
\text { delay, special needs school }\end{array}$ & 19 \\
\hline 24 & female & $\begin{array}{l}\text { c.492delG; } \\
\text { p.Gly165Glufs*2 } \\
\text { (exon 5) }\end{array}$ & 2.8 & 1.25 & $\begin{array}{l}\text { normal MRI scan enlarged } \\
\text { perivascular spaces }\end{array}$ & + & - & - & - & $\begin{array}{l}\text { None, normal intelligence, } \\
\text { secondary school }\end{array}$ & 17 \\
\hline 25 & female & $\begin{array}{c}\text { c.1133_- } \\
\text { 1136del.pArg378ilefs*37 } \\
\text { (exon 9) }\end{array}$ & 3.5 & 1 & $\begin{array}{l}\text { Chiari malformation type I, } \\
\text { enlarged perivascular spaces }\end{array}$ & $?$ & + & - & - & $\begin{array}{l}\text { delay in cross motor skills, } \\
\text { language developmental } \\
\text { delay, kindergarten }\end{array}$ & 29 \\
\hline 26 & female & $\begin{array}{l}\text { c.389G > A; } \\
\text { p.(Arg130 Gln) } \\
\quad(\text { exon 5) }\end{array}$ & 2.3 & 0.8 & $\begin{array}{l}\text { Supraventricular white matter } \\
\text { abnormalities, left-sided; } \\
\text { enlarged perivascular spaces }\end{array}$ & $?$ & + & + & - & $\begin{array}{l}\text { muscle hypotonia, delay in } \\
\text { language and motor } \\
\text { development, kindergarten }\end{array}$ & 28 \\
\hline 27 & female & $\begin{array}{c}\text { c.406T > } \\
\text { C(p.Cys136Arg })\end{array}$ & 3 & n.d. & n.d. & ? & + & + & - & $\begin{array}{l}\text { autism, muscle hypotonia, } \\
\text { delay in language } \\
\text { development, kindergarten }\end{array}$ & 20 \\
\hline
\end{tabular}


a

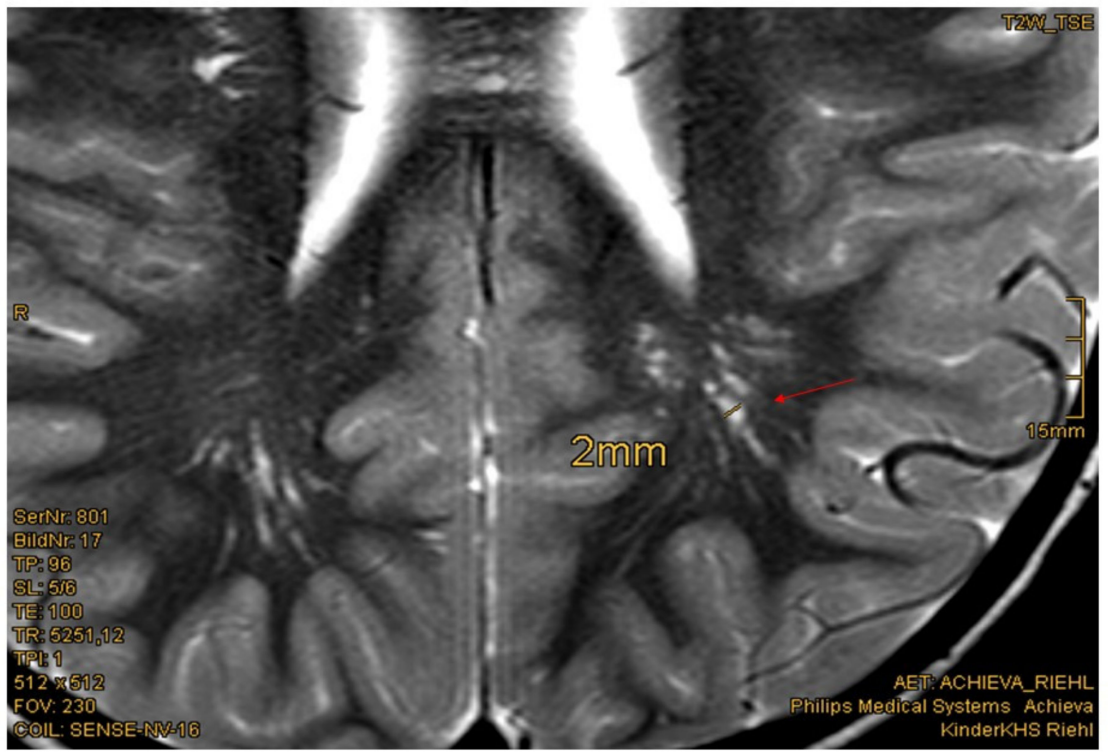

$\mathrm{b}$

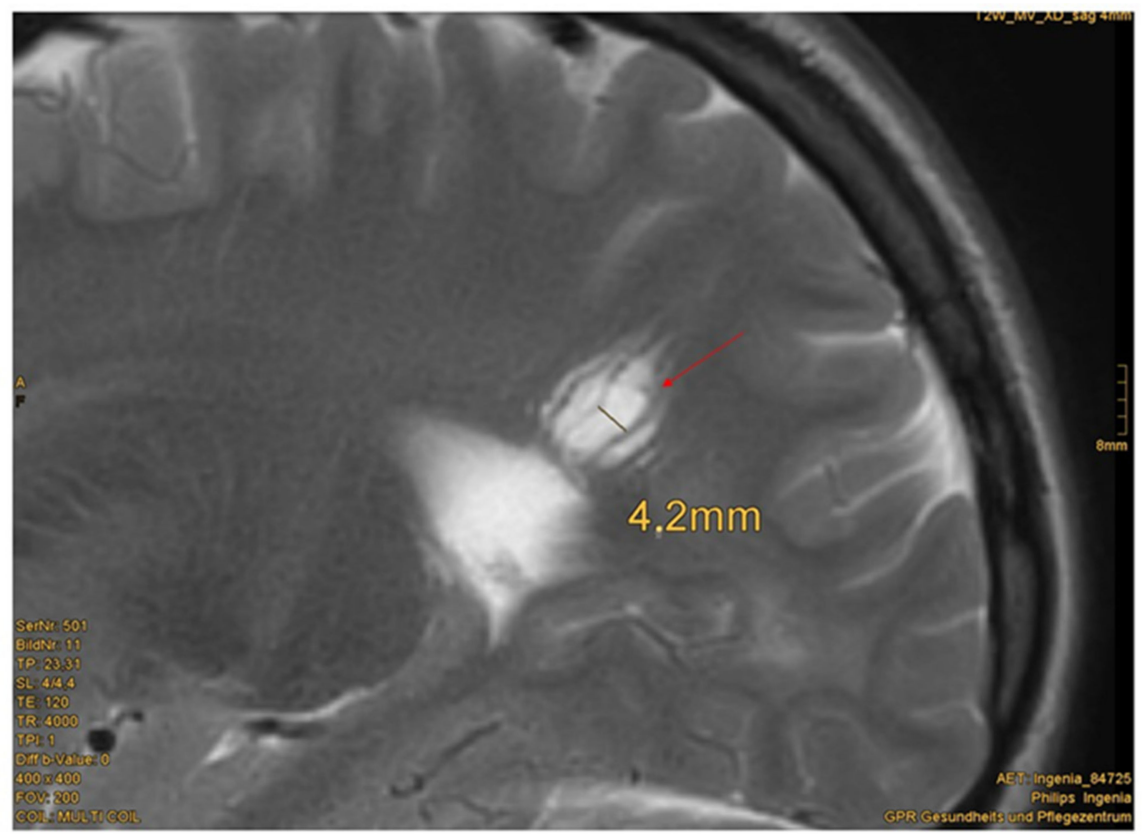

Figure 1. Enlarged perivascular spaces (EPVS) in cerebral MRI (a) Patient 15: 4.5 year-old boy, T2w-image, EPVS 2 mm diameter [Courtesy Kinderkrankenhaus Kliniken der Stadt Köln]. (b) Patient 23: 12.5 year old girl, T2 weighted image, sagittal view, pronounced EPVS up to $3 \mathrm{~mm}$ diameter [Courtesy Dr. A. Wieschen, Institut für Radiologie und Nuklearmedizin, GPR Klinikum Rüsselsheim].

\subsection{Psychomotor Development}

The clinical presentation of our patients was variable. Most infants exhibited a delay of early motor development. The age when patients started walking independently, as one of the important milestones of motor development, ranged from 14 to 30 months in male patients (mean 20 months, median 18 months) and from 13 to 29 months in female patients (mean 21.3, median 20 months).

In twelve patients the treating pediatric neurologists described muscle hypotonia to a variable degree. Most parents reported rapid fatigue when their children needed to walk a longer distance. Two patients needed medical devices (such as a wheelchair) to handle longer distances. Two boys and one girl were tested and diagnosed with an autism spectrum disorder, which was the dominant clinical problem of these patients. One of the boys was seriously affected and presenting with no expressive speech by the age of 12 years. The two other patients suffered from milder forms of 
autism spectrum disorders. The remaining patients had not been tested for autism spectrum disease. Some patients underwent developmental testing. However, since testing was part of the individual clinical routine preceding a diagnosis of PHTS, different test protocols were used, and patients were tested at different (mostly very young) ages. Therefore, it was not possible to compare the results of these tests systematically in this retrospective analysis. The majority of patients who had received IQ testing demonstrated an IQ within the normal range (IQ 85-115), but were reported to have difficulties in logical reasoning, attention and a slow processing speed. For further details of the tested patients (age, testing protocol and results), see Table 1. A greater number of our patients were not tested, because the patients showed no clinical hints for problems regarding their intellectual development. They visited regular schools with appropriate school performances, two had already graduated from secondary school and started university. Overall, intellectual ability was quite variable in this patient group. Behavioral problems were reported in a minor number of our patients, for example obsessive-compulsive disorder, attention deficit hyperactivity disorder (ADHD), autism or impulsivity. For further details see Table 1. Almost all patients were reported to show problems in motor coordination.

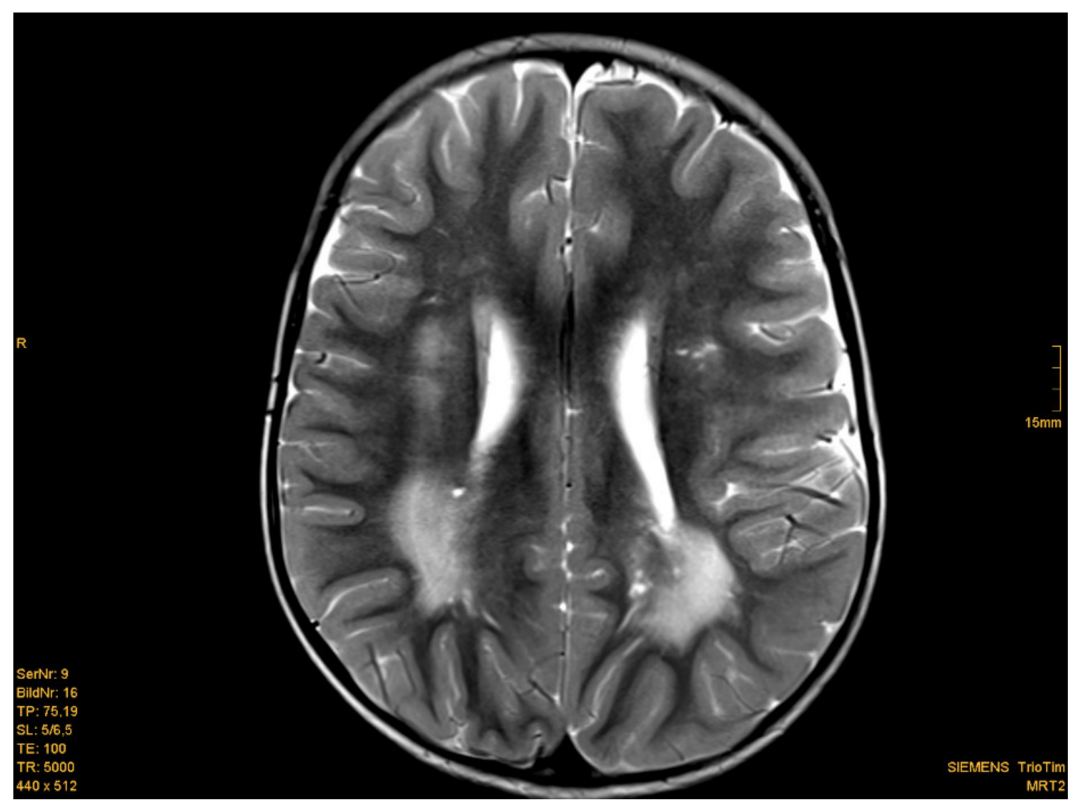

Figure 2. Example of white matter abnormalities. Patient 6: 2 year-old boy, T2 weighted image. Posteriorly increased signal intensity of the white matter. [Courtesy Dr. Scharper, Radiology University Düsseldorf].

\subsection{Additional Phenotypical Features}

We have already published some of the additional phenotypical features (in particular auxology, thyroid pathology) of this cohort elsewhere [2,11].

Thyroid: In this current cohort, 14/27 patients showed a thyroid pathology. Half of them (7/14) had undergone thyroid surgery due to highly suspicious lesions. Histopathological findings included a papillary microcarcinoma in a six-year-old boy and a follicular carcinoma in a 13-year old girl, as well as nodular goiter and follicular adenoma. Other patients demonstrated signs of autoimmune thyroid disease and thyroid nodules or cysts.

Gastrointestinal findings: Colonoscopy had been performed in five patients so far. In four of five patients, multiple polyps of the gastrointestinal tract were found. One patient was a carrier of an additional BMPR1A deletion and thus had to undergo colectomy for disease control.

Skin: Special skin findings in this patient group were penile freckling (in 10 of 18 male patients; $56 \%$ ), lipoma (15/27 patients; $56 \%$ ), hemangioma (5 patients; $18.5 \%$ ) and trichilemmoma in two patients. 


\section{Discussion}

Diagnosis of PHTS in childhood can be challenging. First, PHTS is a rare disease with an estimated prevalence of 1:200,000 to 1:250,000 [16,17] and is therefore still not well known in the medical community. Second, children often do not fulfill the clinical criteria of Cowden Syndrome (CS), which has been established for adults with CS, with CS being the best known condition of the PHTS spectrum $[18,19]$. Pediatric clinical features for PTEN testing have been published by Tan et al. in 2011 [8] and are particularly known by specialists in this field, but a broader knowledge in the pediatric community is lacking. Most children and adolescents present clinical aspects of BRRS, which encompasses macrocephaly, hamartoma (for example lipoma, hemangioma and intestinal polyps) and penile freckling in male patients $[5,6]$, whereas some children only exhibit macrocephaly with a variable degree of developmental delay or cognitive impairment. In the end, BRRS and CS can be seen as one condition with variable expression and age-related penetrance [20].

As mentioned above, macrocephaly is probably the most evident symptom of PHTS in childhood and cerebral MRI is one aspect of its diagnostic workup. In this context, it is useful to distinguish whether the child suffers from megalencephaly, defined by increased growth of cerebral structures, related to dysfunctional anomalies during brain development in the neuronal proliferation/migration or whether the increased head circumference is caused by macrocephaly, which is linked to various events including anomalies of bone, subdural fluid collections, arteriovenous malformations, hydrocephalus or others [21]. Strictly speaking, in most patients with PHTS we should speak of megalencephaly and not macrocephaly [21-23], but in most scientific papers these terms are used interchangeably [20].

As expected, the reason of the increased head circumference in this patient cohort was megalencephaly. In addition, we detected an unexpected high rate $(18 / 19 ; 95 \%)$ of enlarged perivascular spaces (EPVS). Enlarged perivascular spaces or so-called Virchow-Robin Spaces (VRS) are perivascular extensions of the pia mater accompanying the perforating arteries of the brain [24]. They are filled with fluid and can be seen in people of any age, but their prevalence increases with advancing age $[25,26]$. It is not clear, whether they are merely a benign manifestation of ageing or whether EPVS are a form of relatively distinct pathological change seen in the ageing brain and in various disease states. One study found that EPVS were associated with cognitive decline in otherwise healthy elderly men [27].

A high percentage of EPVS in pediatric patients with PTEN mutation and macrocephaly has been described in a previous publication [28]. Vanderver and coauthors described enlarged perivascular spaces with or without periventricular white matter abnormalities as a relatively consistent imaging feature in 23 patients with proven PTEN mutation and macrocephaly.

They concluded that the presence of EPVS and/or white matter abnormalities in patients with macrocephaly and developmental delay or autism spectrum disorder should give reason to test for the PTEN gene mutation. Our results strongly underline this recommendation, since another frequent observation $(37 \%)$ in almost half of our patients were white matter abnormalities. We included one patient with heterozygous deletion of the PTEN and BMPR1A genes who exhibited EPVS and white matter abnormalities. We cannot prove that MRI findings are related to either PTEN or BMPR1A mutation. However, to the best of our knowledge, EPVS as well as white matter abnormalities have only been described in patients with PTEN gene mutation, but not in patients with BMPR1A mutations. Whereas germline mutations in PTEN are associated with macrocephaly, with brain MRI showing markedly larger brain volumes as well as increased white matter hypointensities compared to other patients and healthy controls [28-30]. Patients with white matter abnormalities in our study exhibited a wide clinical spectrum from severe developmental delay to mild muscle hypotonia and normal intelligence. This is in accordance with the results of Balci et al. [13], who first described white matter abnormalities in patients with PTEN gene mutations and otherwise normal development. In contrast, Frazier et al. [31] compared patients with germline heterozygous PTEN mutations and autism spectrum disorder (PTEN-ASD) with idiopathic ASD patients and healthy controls, and found that prominent white matter and cognitive abnormalities were specifically associated with PTEN-ASD patients. White matter abnormalities mediated the relationship between PTEN protein reductions and 
reduced cognitive ability. Intellectual disability was described as a possible clinical sign of patients with the PTEN gene mutation. In our cohort, we found a broad range of intellectual abilities. The majority of our patients demonstrated a mean IQ within the normal range.

This is in accordance with others [30] who tested cognitive function in selected individuals with PTEN mutations and reported that mean IQ was average. A limitation of our retrospective study is that we did not perform a standardized neurodevelopmental evaluation in our patients. Not all patients received IQ testing, sometimes because parents or referring physicians had no evidence for intellectual disabilities. Subjects in whom cognitive testing was performed, were tested at their respective local institutions by different physicians. We were thus unable to give precise information on partial disturbances of performance in this study cohort. Autism spectrum disorder (ASD) or autism spectrum disorder-features were only tested in a minority of our patients, even though we cannot exclude that more patients might have ASD or at least ASD-features, as the prevalence of ASD in PHTS is estimated around $22 \%[8,29]$. A delay in motor development and motor coordination were observed frequently, which could be reflected by the delayed ability of independent walking as a milestone of motor development. Another limitation is that the cMRIs did not follow a uniform examination protocol as they were part of the local clinical work up of macrocephaly. It would be favorable if all children could have been examined at determined ages with a more comparable technical quality.

Coming back to EPVS and white matter abnormalities once more, we agree that EPVS and white matter abnormalities are part of the clinical spectrum of patients with PTEN mutations and do not need further clarifications, if the diagnosis of PHTS has already been made [28]. Even though all MRI findings of our cohort have been described previously, we can underline the high prevalence of EPVS and white matter abnormalities in a relatively large group of pediatric PHTS patients. Since, in our pediatric cohort, EPVS (95\%) and white matter abnormalities (37\%) seem to have a higher or at least equal prevalence to penile freckling (56\%), lipoma (56\%) and hemangioma (18.5\%), we want to emphasize these attributes as new diagnostic features of PHTS in childhood.

In our study cohort, the combination of macrocephaly and EPVS could help to establish the diagnosis of PTEN gene mutation in two cases. But if the association of EPVS and white matter abnormalities were more established and better known as a diagnostic feature of PTEN Hamartoma Tumor Syndrome by pediatricians, pediatric neurologists and radiologists, we are convinced that PTEN gene analysis would be performed earlier and may establish an earlier diagnosis in many cases.

The criteria in Table 2a,b might thus serve as a tool for indicating a molecular diagnostic workup to detect PTEN gene mutation in children and adolescents.

Table 2. Tool for indicating a molecular diagnostic workup to detect PTEN gene mutation in children and adolescents. (a) Major- and minor criteria for indicating molecular testing of the PTEN gene mutation in children and adolescents (modified after [19,32]). (b) (modified after Tan et al. [8]): Clinical criteria for molecular testing of the PTEN gene.

\begin{tabular}{cc}
\hline & (a) \\
\hline Major Criteria & Minor Criteria \\
\hline Macrocephaly & Autism spectrum disorder \\
\hline Positive family history & Mental retardation (i.e., IQ of 75 and below) \\
\hline Facial trichilemmomas $(>/=3)$ & Esophageal acanthosis \\
\hline Oral papilloma & Lipoma \\
\hline Macular pigmentation of glans penis & Testicular cell carcinoma \\
\hline Multiple GI hamartomas or ganglioneuroma & Other thyroid lesions (e.g., adenoma, multinodular goiter) \\
\hline Thyroid carcinoma/adenoma & Vascular anomalies \\
\hline Breast cancer & Enlarged perivascular spaces in cMRI \\
\hline Endometrial cancer & White matter abnormalities \\
\hline
\end{tabular}


Table 2. Cont.

\begin{tabular}{|c|c|c|c|}
\hline \multicolumn{4}{|c|}{ (b) } \\
\hline Analysis of PTEN Gene, If & Macrocephaly Plus & $\begin{array}{c}\text { No } \\
\text { Macrocephaly/Positive } \\
\text { Family History }\end{array}$ & $\begin{array}{c}\text { Positive Family History } \\
\text { (Positive PTEN } \\
\text { Gene Mutation) }\end{array}$ \\
\hline & $\begin{array}{l}\text { At least one of the following } \\
\text { criteria: }\end{array}$ & 2 major criteria & $\begin{array}{l}\text { Genetical testing without any } \\
\text { other criteria, if a parent is } \\
\text { positive for a PTEN } \\
\text { gene mutation }\end{array}$ \\
\hline & $\begin{array}{l}\text { autism spectrum disorder or } \\
\text { developmental delay }\end{array}$ & $\begin{array}{c}1 \text { major criteria } \\
+2 \text { minor criteria }\end{array}$ & \\
\hline & $\begin{array}{l}\text { dermatologic features, } \\
\text { including lipomas, } \\
\text { trichilemmomas, oral } \\
\text { papillomas, penile freckling }\end{array}$ & 3 minor criteria & \\
\hline & vascular pathologies & & \\
\hline & $\begin{array}{l}\text { multiple GI hamartomas or } \\
\text { ganglioneuroma }\end{array}$ & & \\
\hline & $\begin{array}{l}\text { thyroid lesions (especially } \\
\text { adenoma and carcinoma) }\end{array}$ & & \\
\hline & $\begin{array}{l}\text { enlarged perivascular spaces } \\
\text { in cMRI }\end{array}$ & & \\
\hline
\end{tabular}

\section{Conclusions}

EPVS and white matter abnormalities occur at a higher or at least comparably high prevalence compared to penile freckling, lipoma or hemangioma in this pediatric cohort and should therefore be considered as an important diagnostic feature of PHTS in childhood. Most pediatric patients demonstrated a delay in motor development, but processed a normal intelligence, even though intellectual abilities were very variable.

Author Contributions: Conceptualization, P.M., B.M. and W.J.; Data curation, P.M. and B.M.; Formal analysis, P.M. and B.M.; Investigation, P.M., B.M., S.F., S.S., S.V. and W.J.; Methodology, P.M., B.M. and W.J.; Project administration, P.M. and W.J.; Supervision, G.B. and W.J.; Validation, P.M.; Writing-original draft, P.M. and B.M.; Writing-review \& editing, G.B., S.F., S.S., S.V. and W.J. All authors have read and agreed to the published version of the manuscript.

Funding: This research received no external funding.

Acknowledgments: We thank the following institutions for the permission to publish their cerebral MRI pictures: M. Stenzel, Kinderkrankenhaus Kliniken der Stadt Köln, Wieschen, Institut für Radiologie und Nuklearmedizin, GPR Klinikum Rüsselsheim, Schaper, Radiologie Universitätsklinik Düsseldorf.

Conflicts of Interest: The authors declare no conflict of interest.

\section{References}

1. Tan, M.H.; Mester, J.L.; Ngeow, J.; Rybicki, L.A.; Orloff, M.S.; Eng, C. Lifetime cancer risks in individuals with germline PTEN mutations. Clin. Cancer Res. 2012, 18, 400-407. [CrossRef] [PubMed]

2. Plamper, M.; Schreiner, F.; Gohlke, B.; Kionke, J.; Korsch, E.; Kirkpatrick, J.; Born, M.; Aretz, S.; Woelfle, J. Thyroid disease in children and adolescents with PTEN hamartoma tumor syndrome (PHTS). Eur. J. Pediatr. 2018, 177, 429-435. [CrossRef] [PubMed]

3. Smith, J.R.; Marqusee, E.; Webb, S.; Nose, V.; Fishman, S.J.; Shamberger, R.C.; Frates, M.C.; Huang, S.A. Thyroid nodules and cancer in children with PTEN hamartoma tumor syndrome. J. Clin. Endocrinol. Metab. 2011, 96, 34-37. [CrossRef] [PubMed]

4. Smpokou, P.; Fox, V.L.; Tan, W.H. PTEN hamartoma tumour syndrome: Early tumour development in children. Arch. Dis. Child. 2015, 100, 34-37. [CrossRef] 
5. Marsh, D.J.; Kum, J.B.; Lunetta, K.L.; Bennett, M.J.; Gorlin, R.J.; Ahmed, S.F.; Bodurtha, J.; Crowe, C.; Curtis, M.A.; Dasouki, M.; et al. PTEN mutation spectrum and genotype-phenotype correlations in BannayanRiley-Ruvalcaba syndrome suggest a single entity with Cowden syndrome. Hum. Mol. Genet. 1999, 8, 1461-1472. [CrossRef]

6. Parisi, M.A.; Dinulos, M.B.; Leppig, K.A.; Sybert, V.P.; Eng, C.; Hudgins, L. The spectrum and evolution of phenotypic findings in PTEN mutation positive cases of Bannayan-Riley-Ruvalcaba syndrome. J. Med. Genet. 2001, 38, 52-58. [CrossRef]

7. Tan, W.H.; Baris, H.N.; Burrows, P.E.; Robson, C.D.; Alomari, A.L.; Mulliken, J.B.; Fishman, S.J.; Irons, M.B. The spectrum of vascular anomalies in patients with PTEN mutations: Implications for diagnosis and management. J. Med. Genet. 2007, 44, 594-602. [CrossRef]

8. Tan, M.H.; Mester, J.; Peterson, C.; Yang, Y.; Chen, J.L.; Rybicki, L.A.; Milas, K.; Pederson, H.; Remzi, B.; Orloff, M.S.; et al. A clinical scoring system for selection of patients for PTEN mutation testing is proposed on the basis of a prospective study of 3042 probands. Am. J. Hum. Genet. 2011, 88, 42-56. [CrossRef]

9. Kato, K.; Mizuno, S.; Inaba, M.; Fukumura, S.; Kurahashi, N.; Maruyama, K.; Leda, D.; Ohashi, K.; Hori, I.; Negishi, Y.; et al. Distinctive facies, macrocephaly, and developmental delay are signs of PTEN mutation in childhood. Brain Dev. 2018, 40, 678-684. [CrossRef]

10. Busa, T.; Milh, M.; Degardin, N.; Girard, N.; Sigaudy, S.; Longy, M.; Olshchwang, S.; Sobol, H.; Chabrol, B.; Philip, N. Clicical presentations of PTEN mutations in childhood in the absence of family history of Cowden syndrome. Eur. J. Paediatr. Neurol. 2015, 19, 188-192. [CrossRef]

11. Plamper, M.; Gohlke, B.; Schreiner, F.; Woelfle, J. Phenotype-Driven Diagnostic of PTEN Hamartoma Tumor Syndrome: Macrocephaly, But Neither Height nor Weight Development, Is the Important Trait in Children. Cancers 2019, 11, 975. [CrossRef] [PubMed]

12. Lok, C.; Viseux, V.; Avril, M.F.; Richard, M.A.; Gondry-Jouet, C.; Deramond, H.; Desfossez-Tribout, C.; Courtade, S.; Delaunay, M.; Piette, F.; et al. Cancerology Group of the French Society of Dermatology. Brain magnetic resonance imaging in patients with Cowden syndrome. Medicine (Baltimore) 2005, 84, 129-136. [CrossRef]

13. Balci, T.B.; Davila, J.; Lewis, D.; Boafo, A.; Sell, E.; Richer, J.; Nikkel, S.M.; Armour, C.M.; Tomiak, E.; Lines, M.A.; et al. Broad spectrum of neuropsychiatric phenotypes associated with white matter disease in PTEN hamartoma tumor syndrome. Am. J. Med. Genet. Part B 2018, 177, 101-109. [CrossRef] [PubMed]

14. Dhamija, R.; Weindling, S.M.; Porter, A.B.; Hu, L.S.; Wood, C.P.; Hoxworth, J.M. Neuroimaging abnormalities in patients with Cowden syndrome: Retrospective single-center study. Neurol. Clin. Pract. 2018, 8, $207-213$. [CrossRef] [PubMed]

15. Shiohama, T.; Levman, J.; Vasung, L.; Takahashi, E. Brain morphological analysis in PTEN hamartoma tumor syndrome. Am. J. Med. Genet. A 2020, 182, 1117-1129. [CrossRef]

16. Farooq, A.; Walker, L.J.; Bowling, J.; Audisio, R.A. Cowden syndrome. Cancer Treat. Rev. 2010, 36, 577-583. [CrossRef]

17. Nelen, M.R.; Kremer, H.; Konings, I.B.; Schoute, F.; van Essen, A.J.; Koch, R.; Woods, C.G.; Fryns, J.P.; Hamel, B.; Hoefsloot, L.H.; et al. Novel PTEN mutations in patients with Cowden disease: Absence of clear genotype-phenotype correlations. Eur. J. Hum. Genet. 1999, 7, 267-273. [CrossRef]

18. Pilarski, R.; Burt, R.; Kohlman, W.; Pho, L.; Shannon, K.M.; Swisher, E. Cowden syndrome and the PTEN hamartoma tumor syndrome: Systematic review and revised diagnostic criteria. J. Natl. Cancer Inst. 2013, 105, 1607-1616. [CrossRef]

19. Daly, M.B.; Pilarski, R.; Axilbund, J.E.; Buys, S.S.; Crawford, B.; Friedman, S.; Garber, J.E.; Horton, C.; Kaklamani, V.; Klein, C.; et al. Genetic/Familial High-Risk Assessment: Breast and Ovarien, Version 1. J. Natl. Compr. Cancer Netw. 2014, 12, 1326-1338. [CrossRef]

20. Lachlan, K.L.; Lucassen, A.M.; Bunyan, D.; Temple, I.K. Cowden syndrome and Bannayan Riley Ruvalcaba syndrome represent one condition with variable expression and age-related penetrance: Results of a clinical study of PTEN mutation carriers. J. Med. Genet. 2007, 44, 579-585. [CrossRef]

21. Pavone, P.; Pratico, A.D.; Rizzo, R.; Corsello, G.; Ruggieri, M.; Parano, E.; Falsaperla, R. A clinical review on megalencephaly: A large brain as a possible sign of cerebral impairment. Medicine 2017, 96, e6814. [CrossRef] [PubMed] 
22. Mirzaa, G.M.; Riviere, J.B.; Dobyns, W.B. Megalencephaly syndromes and activation mutatons in the PI3K-AKT pathway: MPPH and MCAP. Am. J. Med. Genet. C Semin. Med. Genet. 2013, 163, 122-130. [CrossRef] [PubMed]

23. Mirzaa, G.M.; Pduri, A. Megalencephaly and hemimegalencephaly: Breaktroughs in molecular etiology. Am. J. Med. Genet. C Semin. Med. Genet. 2014, 166, 156-172. [CrossRef] [PubMed]

24. Eichhorn, G.R.; Ammache, Z.; Bell, W.; Yuh, W.T. Unusually prominent perivascular spaces. Neurology 2011, 56, 1242. [CrossRef] [PubMed]

25. Heier, L.A.; Bauer, C.J.; Schwartz, L.; Zimmerman, R.D.; Morgello, S.; Deck, M.D. Large Virchow-Robin spaces: MR-clinical correlation. AJNR Am. J. Neuroradiol. 1989, 10, 929-936. [PubMed]

26. Rudie, J.D.; Rauschecker, A.M.; Nabavizadeh, S.A.; Mohan, S. Neuroimaging of Dilated Perivascular spaces: From Benign and Pathologic Causes to Mimics. J. Neuroimaging 2018, 28, 139-149. [CrossRef] [PubMed]

27. MacLullich, A.M.; Wardlaw, J.M.; Ferguson, K.J.; Starr, J.M.; Seckl, J.R.; Deary, I.J. Enlarged perivascular spaces are associated with cognitive function in healthy elderly men. J. Neurol. Neurosurg. Psychiatry 2004, 75, 1519-1523. [CrossRef]

28. Vanderver, A.; Tonduti, D.; Kahn, I.; Schmidt, J.; Medne, L.; Vento, J.; Van Der Knaap, M.S. Characteristic brain magnetic resonance imaging pattern in patients with macrocephaly and PTEN mutations. Am. J. Med. Genet. Part A 2014, 164, 627-633. [CrossRef]

29. Busch, R.M.; Strivasta, S.; Hogue, O.; Frazier, T.W.; Klaas, P.; Hardan, A.; Martinez-Agosto, J.A.; Sahin, M.; Eng, C. Developmental Synaptopathies Consortium, Neurobehavioral phenotype of autism spectrum disorder associated with germline heterozygous mutations in PTEN. Transl. Psychiatry 2019, 9, 253. [CrossRef]

30. Busch, R.M.; Chapin, J.S.; Mester, J.; Fergueson, L.; Haut, J.S.; Frazier, T.W.; Eng, C. The Cognitive Characteristics of PTEN Hamartoma Tumor Syndromes. Genet. Med. 2013, 15, 548-553. [CrossRef]

31. Frazier, T.W.; Embacher, R.; Tilot, A.K.; Koenig, K.; Mester, J.; Eng, C. Molecular and phenotypic abnormalities in individuals with germline heterozygous PTEN mutations and autism. Mol. Psychiatry 2015, 20, 1132-1138. [CrossRef] [PubMed]

32. AWMG Guidelins: S1-Leitlinie. Diagnostik und Management von Patientin mit PTEN Hamartom Tumor Syndrom (PHTS) im Kinder- und Jugendalter. Registernr.: 174-025. Available online: https://www.awmf.org/ leitlinien/detail/1l/174-025.html (accessed on 30 October 2019).

(C) 2020 by the authors. Licensee MDPI, Basel, Switzerland. This article is an open access article distributed under the terms and conditions of the Creative Commons Attribution (CC BY) license (http://creativecommons.org/licenses/by/4.0/). 